\title{
Forskningsnytt
}

Nytt fra internasjonal forskning presentert og kommentert av Anners Lerdal, redaktør i Sykepleien Forskning og seniorforsker ved Lovisenberg diakonale sykehus og Oslo Universitetssykehus.

\section{Fatigue hos personer med kronisk tarmbetennelsene}

Tidligere studier viser at personer med kroniske sykdommer og fatigue har redusert helserelatert livskvalitet. Dette fenomenet er lite studert hos pasienter med inflammatorisk tarmsykdom. Hensikten med studien var derfor å undersøke sammenhengen mellom fatigue og selvrapportert livskvalitet hos personer i denne pasientgruppen. Pasienter med ulcerøs kolitt og Crohns sykdom enten i remisjon eller med

Artikkelen viser store forskjeller i helserelatert livskvalitet mellom personer som har vært plaget med fatigue over lang tid sammenliknet med dem som ikke har vært plaget av fatigue. Funnet understreker viktigheten av at helsepersonell som arbeider med denne gruppen pasienter er oppmerksomme på tegn og symptomer på fatigue og veileder dem i strategier for å mestre fatigue i hverdagen. mild og moderat sykdomsaktivitet, ble rekruttert fra tre poliklinikker til å delta i tverrsnittsstudien. Ved hjelp av spørreskjemaer ble det samlet inn informasjon om sosiodemografiske variabler og røykevaner. I tillegg fylte de ut spørreskjema om helserelatert livskvalitet (Short-Form 36 [SF-36]) og den norske versjonen av Inflammatory Bowel Disease Questionnaire (IBDQ). Fatigue ble målt ved hjelp av spørreskjemaet Fatigue Questionnaire. Dette består av syv spørsmål som måler fysisk fatigue og fire som måler mental fatigue. Hvis man skårer høyt på minst fire av disse spørsmålene og oppgir at tretthet og utmattelse har vart i mer enn seks måneder, blir tilstanden definert som langvarig fatigue. Utvalget ble delt i to ut fra denne definisjonen. Gruppen med langvarig fatigue utgjorde 24 prosent av utvalget. Om pasientene hadde langvarig fatigue eller ikke, var ikke relatert til alder, kjønn, utdanningsnivå eller sivil status. Men gruppen med langvarig fatigue hadde en større andel som røykte. Blant pasientene med ulcerøs kolitt oppga de med langvarig fatigue en betydelig lavere livskvalitet, knyttet til rollebegrensninger på grunn av fysiske og emosjonelle problemer, enn de uten langvarig fatigue. I gruppen av pasienter med Crohns sykdom rapporterte pasienter med langvarig fatigue betydelig større problemer knyttet til rollebegrensninger på grunn av fysiske problemer. mer smerter, lavere generell helse, mindre vitalitet og dårligere sosial funksjon sammenliknet med dem uten langvarig fatigue.

\section{REFERANSE:}

Jelsness-Jorgensen LP, Bernklev T, Henriksen M, Torp R, Moum BA. Chronic fatigue is associated with impaired healthrelated quality of life in inflammatory bowel disease. Aliment Pharmacol Ther 2011:33:106-14

\section{Barrierer for godt tannstell på sykehjem}

Motstand fra pasientene og mangel på tid hos sykepleiere var den viktigste grunnen til ikke å utføre regelmessig og godt tannstell.

Sykepleierne har ansvar for at pasienter på sykehjem får nødvendig hjelp til tannstell. Hensikten med unders $\varnothing$ kelsen var å utforske pasienters og sykepleieres vurdering av hindringer for å gjennomføre tannstell hos pasienter innlagt på sykehjem.

Studien hadde et tverrsnittsde- sign hvor tannstatus til 527 pasienter ble undersøkt av tannpleier. I tillegg besvarte 494 helsepersonell et spørreskjema. Svarprosenten var 73. Studien ble gjennomført i Østfold på 11 sykehjem i 2010. I denne gruppen var 114 autoriserte sykepleiere, 243 hjelpepleiere/omsorgsarbeidere og 136 assistenter.

Tannpleiere vurderte pasientenes tenner ut fra en tannhelseindeks (mucosal plaque index) med sumskår fra 2 til 8. Tannhelsen til pasienter som fikk skåren 5 eller høyere ble klassifisert som dårlig. I tillegg ble opplysninger om pasientenes kognitive status, om de trengte hjelp til tannstell og hvor ofte de gjorde tegn til motstand mot tannstell registrert. Data innsamlet med spørreskjemaet omhandlet hjelpernes holdninger, atferd og kunnskaper om tannstell samt yrkeserfaring.

Studien viste at 48 prosent av pasientene hadde flere enn ti tenner og at 41 prosent av alle pasien- 


\section{$>$ TIPS OSS}

Kjenner du til nye studier presentert i internasjonale tidsskrift som du mener har klinisk relevans og interesse for nor ske sykepleiere?

Tips kan sendes til anners.lerdalalds.no

\section{Depressive symptomer etter hjerneslag}

$\AA$ A $æ r e$ deprimert etter hjerneslaget var som å leve et liv i grånyanser.

Tidligere studier har vist at over en fjerdedel av pasientene opplever depresjon etter et hjerneslag. Forskerne ønsket å beskrive hvordan depresjon oppleves i den tidlige fasen etter hjerneslag og hvordan det var å leve med depresjon i denne tiden. Studien var designet som en kvalitativ studie med et hermeneutisk fenomenologisk perspektiv. Ni personer ble rekruttert til studien fra ulike slagenheter. Inklusjonskriteriene var gjennomgått første gangs hjerneslag, over 18 år, skår på Beck Depression Inventory versjon II som var høyere enn 14 eller diagnostisert med depresjon av en lege og god nok kognitiv funksjon til å la seg intervjue. Personer som hadde brukt antidepressiva før hjerneslaget, hadde en terminal diagnose eller fikk behandling for en bipolar lidelse, ble ikke inkludert i studien. Data ble samlet inn ved hjelp av dybdeintervju som varte fra 45-90 minutter i perioden fire til syv uker etter slaget. En tematisk intervjuguide ble brukt som utgangspunkt for å innhente rike beskrivelser av personens opplevelser og erfaringer. Intervjuene ble tolket ut fra tre nivåer: Naiv lesning, strukturell analyse og helhetlig forståelse. Metaforen «å leve et liv i grånyanser» beskriver hovedinnholdet $i$ intervjuene. «Å føle seg fanget» og «å miste seg selv» ble identifisert som to hovedtemaer. A føle seg fanget inkluderte å være fanget i kroppen, fanget i kjedsomhet og isolasjon og fanget $\mathrm{i}$ «for sikkerhets skyld-tenkning». A miste seg selv handlet om ikke lenger å være den samme, å være labil, å føle seg som ingenting og å være for trett til å leve. Deltakerne omtalte ikke sin depresjon med typiske psykiatriske termer, men heller innvevd $i$ historier. Tre beskrev seg selv spontant som deprimert, fire brukte ikke ordet depresjon i løpet av samtalen og to beskrev seg selv som ikke deprimert.

\section{REFERANSE}

Kouwenhoven SE, Kirkevold M, Engedal K, Kim HS. «Living a life in shades of grey»: experiencing depressive symptoms in the acute phase after stroke. J Adv Nurs 2011.

Selv om informantene ble klassifisert som deprimert ut fra skårer i et internasjonalt anerkjent kartleggingsverktøy, var det stor variasjon i måten de omtalte sin depressive tilstand på. Dette viser viktigheten av å være sensitiv overfor symptomer og tegn på depresjon hos pasienter som nylig har gjennomgått hjerneslag. tene hadde dårlig tannhelse. Det var ikke forskjell i tannhelsen mellom de som fikk hjelp av helsepersonell til tannstell og de som pusset tenner selv eller i forhold til graden av pasientenes kognitive svikt. Pasienter som hadde mer enn ti tenner og pasienter som gjorde motstand overfor personalet mot tannstell hadde økt risiko for dårlig tannhelse. Hele 97 prosent av helsepersonellet rapporterte at de opplevde at pasienter daglig gjorde motstand mot tannstell, og 62 prosent oppga at det var vanskelig å prioritere nok tid til å hjelpe pasientene med nødvendig tannstell. Da personalet ble spurt om de hadde nok kunnskaper om tannstell, rapporterte yrkesgruppen med høyere utdanning at de hadde mer kunnskaper enn det de med lavere kompetanse oppga.

\section{REFERANSE:}

Willumsen T, Karlsen L, Naess R, Bjorntvedt S. Are the barriers to good oral hygi- ene in nursing homes within the nurses or the patients? Gerodontology 2011.

Studien viser at sykepleierne som er ansvarlige for at pasienter på sykehjem får nødvendig hjelp til tannstell har forbedringspotensial. Dette vil kreve enda mer oppmerksomhet i fremtiden siden pasienter på sykehjem i økende grad har flere tenner enn tidligere. 